\title{
Detection of Polymorphisms of DNA Repair Genes (XRCC1 and XPC) in Prostate Cancer"
}

\author{
Amani Fouad Sorour ${ }^{1}$, Iman Mamdouh Talaat ${ }^{2 \#}$, Tamer Mohammed Abou Youssif ${ }^{3}$, \\ Mohamed Adel Atta ${ }^{3}$ \\ ${ }^{1}$ Department of Clinical Pathology, Faculty of Medicine, Alexandria University, Alexandria, Egypt; ${ }^{2}$ Department of Pathology, Fac- \\ ulty of Medicine, Alexandria University, Alexandria, Egypt; ${ }^{3}$ Department of Genitourinary, Faculty of Medicine, Alexandria Univer- \\ sity, Alexandria, Egypt. \\ Email: \#iman_talaat@yahoo.com
}

Received November $23^{\text {rd }}, 2013$; revised December $13^{\text {th }}, 2013$; accepted December $20^{\text {th }}, 2013$

Copyright (C) 2013 Amani Fouad Sorour et al. This is an open access article distributed under the Creative Commons Attribution License, which permits unrestricted use, distribution, and reproduction in any medium, provided the original work is properly cited. In accordance of the Creative Commons Attribution License all Copyrights (C) 2013 are reserved for SCIRP and the owner of the intellectual property Amani Fouad Sorour et al. All Copyright (C) 2013 are guarded by law and by SCIRP as a guardian.

\begin{abstract}
Prostate cancer is a common disease with a multifactorial and complex etiology. It is the most common male malignancy and the second leading cause of death in many countries. The widespread use of PSA testing has increased the detection of this cancer at earlier stages, although this diagnostic method has proved to be insufficient to identify the disease. DNA in most cells is regularly damaged by endogenous and exogenous mutagens. At least four main partially overlapping damage repair pathways operate in mammals. Common polymorphisms in DNA repair genes may alter protein function and an individual's capacity to repair damaged DNA; deficits in repair capacity may lead to genetic instability and carcinogenesis. In the present study, we investigated the genotypic distribution of XRCC1 and XPC polymorphisms and its association with prostate cancer risk, pathological staging and Gleason's scoring. The present study was conducted in the departments of Clinical Pathology, Pathology, and Urology Faculty of Medicine, Alexandria University-Egypt. A total number of 50 patients with pathologically confirmed prostate cancer and 50 age-matched control subjects were enrolled in this study. The diagnosis was made on the basis of histopathological findings, following radical prostatectomy or transurethral resection of the prostate (TURP). Genomic DNA was extracted from peripheral blood using QIAamp blood DNA isolation kits. PCR followed by enzymatic digestion of the PCR products for (XRCC1, XPC) was used for the genotyping of these polymorphisms. Statistical analyses were performed using SPSS statistics version 20 . The genotype frequencies of the studied polymorphisms in all the samples $(\mathrm{n}=100)$, PC patients $(\mathrm{n}=50)$ and healthy controls $(\mathrm{n}=50)$ were consistent with the Hardy-Weinberg equilibrium distribution $(\mathrm{p}$-value $>$ 0.05). There was no statistical difference in the genotypes of the XRCC1 Arg399Gln and XPC Lys939Gln between cases and controls. The "Gln" allele frequency of XPC Lys939Gln as well as the "Gln" allele frequency of XRCC1 Arg399Gln tended to be lower in controls than in PC patients. Yet, these decreases were not statistically significant. We also examined the combined effect of XPC and XRCC1 and we found a decreased PC risk when XPC 939 Lys/Lys + Lys/Gln and XRCC1 $399 \mathrm{Arg} / \mathrm{Arg}+\mathrm{Arg} / \mathrm{Gln}$ are combined $(\mathrm{OR}=0.370,95 \% \mathrm{CI}=0.142-0.962)$.
\end{abstract}

Keywords: Prostate Cancer; Polymorphisms; PCR; XRCC1; XPC

\section{Introduction}

Prostate cancer is a common disease with a multifactorial and complex etiology. It is the most common male malignancy and the second leading cause of death in many countries [1]. Several risk factors such as ethnicity, fam-

\footnotetext{
*Conflict of interest: The authors report no conflict of interest.

${ }^{*}$ Corresponding author.
}

ily history, and age have been shown to be associated with the increased prostate cancer risk [2].

The widespread use of PSA testing has increased the detection of this cancer at earlier stages, although this diagnostic method has proved to be insufficient to identify the disease [3].

Pathological staging and Gleason scores for grading are the most important prognostic factors but they have 
been shown to imperfectly discriminate patients at risk for progression [3]. Therefore, research has been directed toward identifying molecular markers that can predict prostate cancer predisposition and progression.

DNA in most cells is regularly damaged by endogenous and exogenous mutagens. Unrepaired damage can lead to effects, triggering cell-cycle arrest or cell death, or long term effects in the form of irreversible mutations contributing to oncogenesis [4].

At least four main partially overlapping damage repair pathways operate in mammals, namely, nucleotide-excision repair (NER), base-excision repair (BER), homologous recombination and end joining [4].

Common polymorphisms in DNA repair genes may alter protein function and an individual's capacity to repair damaged DNA; deficits in repair capacity may lead to genetic instability and carcinogenesis [5]. There is emerging evidence that polymorphic genes may modulate effects of endogenous androgens or environmental toxicans on prostate cancer risk [6].

The xeroderma pigmentosum complementation group C (XPC) protein plays a key role in NER pathway. The functional DNA-binding domains of XPC interact with HR23B to form a complex that recognizes and binds to the sites of DNA damage. Deficiency in XPC has been involved in tumorigenesis [7].

The X-ray cross complementing group 1 (XRCC1) is one of the enzymes participating in the BER pathway and acts as a scaffolding intermediate by interacting with ligase III, DNA polymerase-B and poly (ADP-ribose) polymerase [8].

In the present study, we investigated the genotypic distribution of XRCC1 and XPC polymorphisms and its association with prostate cancer risk, pathological staging and Gleason's scoring.

\section{Subjects and Methods}

The present study was conducted in the departments of Clinical Pathology, Pathology, and Urology Faculty of Medicine, Alexandria University-Egypt. A total number of 50 patients with pathologically confirmed prostate cancer and 50 age-matched control subjects were enrolled in this study. The diagnosis was made on the basis of histopathological findings, following radical prostatectomy or transurethral resection of the prostate (TURP). The cases were classified according to the WHO criteria, and staged according to the tumor-node-metastasis (TNM) classification and the Gleason grading system. The range of age of the included patients and controls was 40 - 80 years. Controls were apparently healthy subjects on medical examination. Informed consent was obtained from all subjects included in this study according to the Ethical Committee for Human Research in Alexandria Main University Hospital. Samples (peripheral blood and prostatic tissue biopsy) were collected from Urology Department; Faculty of Medicine, Alexandria University over 1 year between 2010 and 2011.

\section{PCR-RFLP genotyping}

Genomic DNA was extracted from peripheral blood using QIAamp blood DNA isolation kits (Qiagen, Crawley, United Kingdom) according to the manufacturer's protocol.

\subsection{Polymerase Chain Reaction (PCR)-Restriction Fragment Length Polymorphism (RFLP) Analysis}

PCR followed by enzymatic digestion of the PCR products for (XRCC1, XPC) was used for the genotyping of these polymorphisms. Amplification reactions were performed in a total volume $50 \mu \mathrm{l}$ containing $50-100 \mathrm{ng}$ DNA and 20 pmol each primer. 2X PCR master mix (Fermentas Life Science) was used. It is composed of: dNTPs (dATP, dCTP, dGTP, and dTTP) $0.4 \mathrm{mM}$ of each, $\mathrm{MgCl} 2(4 \mathrm{mM})$ and 0.05 units $/ \mathrm{ml}$ of Taq polymerase in reaction buffer. Samples were amplified by DNA thermal cycler (Techne Cambridge LTD) for XRCC1 Arg399Gln, and XPC Lys939Gln. The PCR program had an initial denaturation step of $7 \mathrm{~min}$ at $94^{\circ} \mathrm{C}$ followed by 35 cycles of $30 \mathrm{~s}$ at $94^{\circ} \mathrm{C}, 45 \mathrm{~s}$ of annealing at $57^{\circ} \mathrm{C}-62^{\circ} \mathrm{C}$ based on the primers and $45 \mathrm{~s}$ at $72^{\circ} \mathrm{C}$.

\subsection{XRCC1 Arg399GIn Polymorphism}

The XRCC1 Arg399Gln polymorphism was amplified in a 616-bp fragment by using the following primers:

xrcc1-399F (5'-TTGTGCTTTCTCTGTGTCCA-3') and xrcc1-399R (5'-TCCTCCAGCCTTTACTGATA-3'). The PCR product was digested with Fast Digest MspI (Fermentas, life scince). The recognition site for the MspI restriction endonuclease is present only in the Arg (WT) allele; hence, digestion of the Arg allele results in products of $376 \mathrm{bp}$ and $240 \mathrm{bp}$, whereas the Gln allele remains undigested.

\subsection{XPC Lys939GIn Polymorphism}

The XPC Lys939Gln polymorphism was amplified in a 281-bpfragment by using the following primers:

xpc-939F (5'-ACCAGCTCTCAAGCAGAAGC-3') and $\mathrm{xpc}-939 \mathrm{R}$ (5'-CTGCCTCAGTTTGCCTTCTC-3'). The PCR product was digested with Fast Digest PvuII (Fermentas, life scince). The wild (WT/AA) allele remains undigested, hence Lys digestion (AA) gives 280 bp and variant digestion $(\mathrm{Gln} / \mathrm{CC})$ gives 150 and $131 \mathrm{bp}$ fragments .

Fast Digest enzymes (Fermentas, Life science) are advanced line of restriction enzymes for rapid DNA digestion in 5-15 minutes supplied with $10 \times$ Fast Digest buffer $1 \mu 1$ of Fast Digest enzyme is formulated to digest 
up to $0.2 \mu \mathrm{g}$ of PCR product in 5 minutes.

Each restriction digestion reaction $(30 \mu \mathrm{l})$ involved the following components at room temperature in the following order: $17 \mu \mathrm{l}$ water nuclease free, $2 \mu 110 \times$ Fast Digest buffer, $10 \mu 1$ PCR product and $1 \mu$ Fast Digest enzyme. Then the components were mixed up gently and spun down and then incubated at $37^{\circ} \mathrm{C}$ for $5-10 \mathrm{~min}$.

The digested products were resolved on 3\% agarosre gel, stained with ethidium bromide and analyzed under UV light.

\subsection{Statistical Methodology}

Statistical analyses were performed suing SPSS ${ }^{\circledR}$ Statistics version 20 (IBM Corp., New York, USA). Association between categorical variables was tested using Chisquare test (X2). When more than $20 \%$ of the cells have expected count less than 5 , correction for chi-square was conducted using Firsher's Exact test(FEP). Odds ratio (OR) and the corresponding 95\% confidence interval (CI) were computed to quantify the risk associated with gene polymorphism. Significance test results are quoted as two-tailed probabilities and judged at the 5\% level.

\section{Results}

1. Clinico-pathological criteria of the patients:

The present study included 50 patients diagnosed with prostatic cancer and 50 age-matched controls.

Table 1 shows that the mean age of the patients was $65.4 \pm 8.7$. The average Gleason sum was $6.8 \pm 1.6$, their serum PSA was greatly variable ranging from 4 to 297 $\mathrm{ng} / \mathrm{ml}$ with a median value of 48 . Most of the $50 \mathrm{PC}$ patients were of grade T2 \& T3 ( $\mathrm{n}=40,80 \%)$, had no nodal metastasis (N0) $(32,64 \%)$. Nearly half of them were classified as stage II (52\%).

2. Hardy-Weinberg equilibrium:

The genotype frequencies of the studied polymorphisms in all the samples $(\mathrm{n}=100)$; PC patients $(\mathrm{n}=50)$ and healthy controls $(n=50)$ were consistent with the Hardy-Weinberg equilibrium distribution (p-value > $0.05)$.

3. XRCC1 Arg399Gln and XPC Lys939Gln polymorphisms:

Table 2 shows the genotype distribution of the XRCC1 Arg399Gln and XPC Lys939Gln polymorphisms between the PC cases and controls. There was no statistical difference in the genotypes of the XRCC1 Arg399Gln and XPC Lys939Gln between cases and controls.

The frequencies of the variant alleles between cases and controls were as follows: XPC Lys939Gln (0.43, $0.37)$ and XRCC1 Arg399Gln $(0.29,0.23)$ (Table 3) (Figures 1 and 2).

The "Gln" allele frequency of XPC Lys939Gln as well as the "Gln" allele frequency of XRCC1 Arg399Gln
Table 1. Characteristics of PC patients.

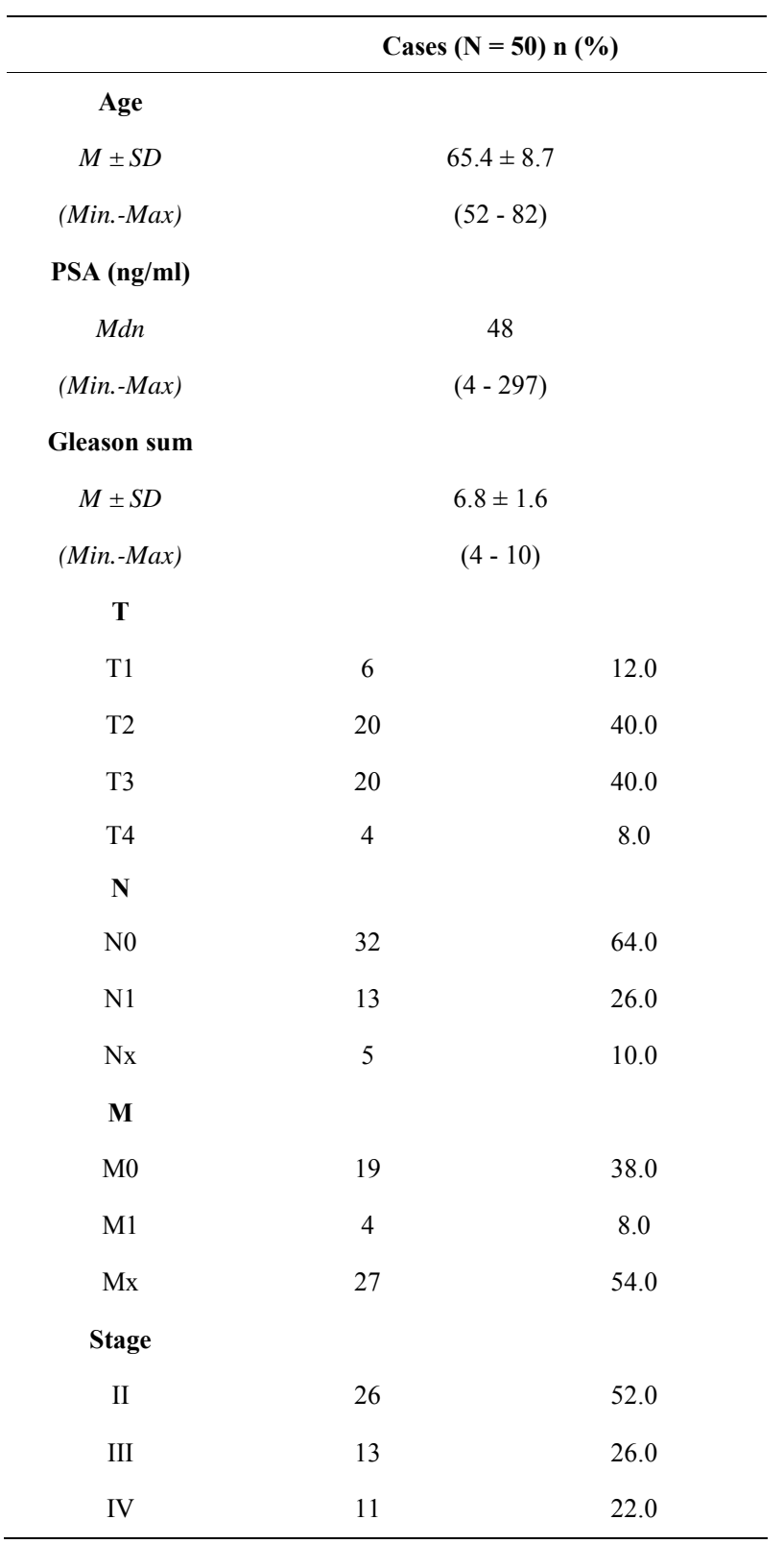

tended to be lower in controls than in PC patients. Yet, these decreases were not statistically significant.

We also examined the combined effect of XPC and XRCC1 and we found a decreased PC risk when XPC 939 Lys/Lys + Lys/Gln and XRCC1 399 Arg/Arg + $\mathrm{Arg} / \mathrm{Gln}$ are combined $(\mathrm{OR}=0.370,95 \% \mathrm{CI}=0.142-0.962)$ (Table 4).

4. Relation of the XPC polymorphism with clinical parameters in $\mathrm{PC}$ patients:

Table 5 shows the relation of XPC polymorphisms with clinic-pathological parameters including age of onset, Gleason score, and the stage of the tumor in PC patients.

The frequency of Gln/Gln genotype of the XPC tended 
Table 2. Distribution of two DNA repair gene polymorphisms in PC patients and controls.

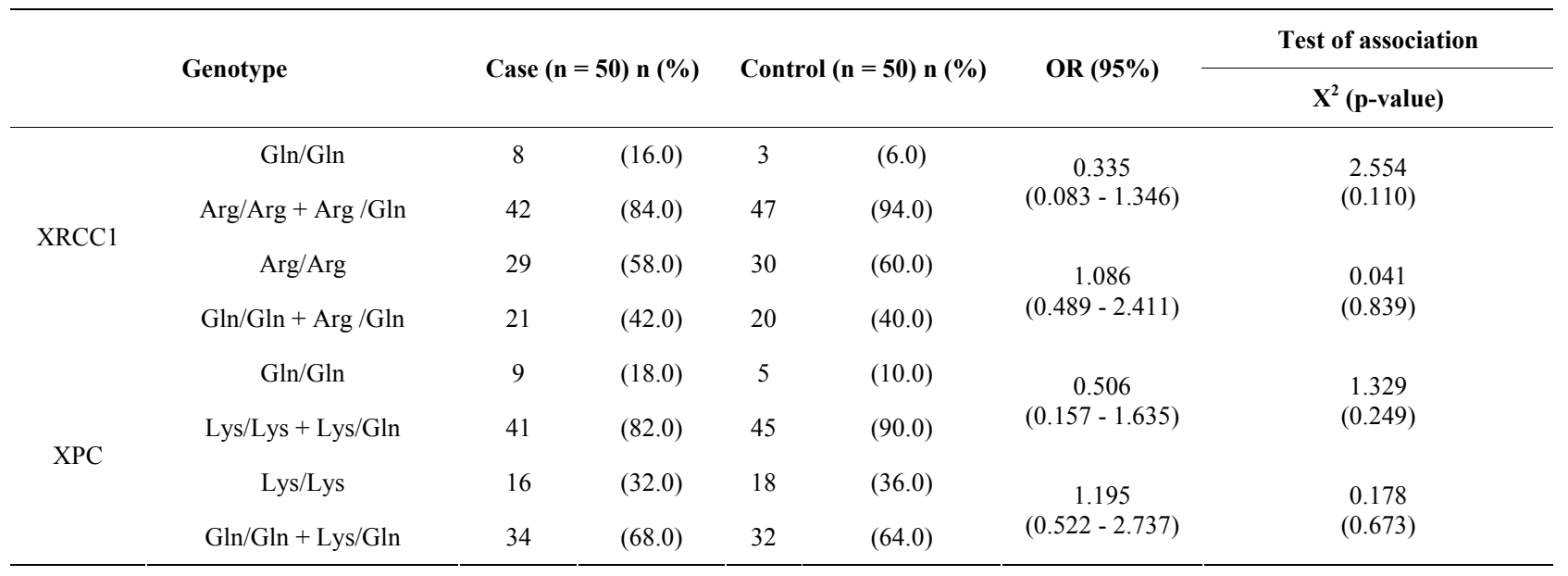

Table 3. Comparison of the allele frequency of XPC Lys939GIn and XRCC1 Arg399GIn between PC patients and healthy controls.

\begin{tabular}{|c|c|c|c|c|c|c|c|}
\hline \multirow{2}{*}{\multicolumn{2}{|c|}{ Genotype }} & \multirow{2}{*}{\multicolumn{2}{|c|}{ Case (Alleles no. $=100)$ n $(\%)$}} & \multirow{2}{*}{\multicolumn{2}{|c|}{ Control (Alleles no. $=100)$ n $(\%)$}} & \multirow{2}{*}{ OR $(95 \%)$} & \multirow{2}{*}{$\frac{\text { Test of association }}{\mathbf{X}^{2} \text { (p-value) }}$} \\
\hline & & & & & & & \\
\hline \multirow{2}{*}{ XRCC1 } & Arg & 71 & (71) & 77 & (77) & \multirow{2}{*}{$\begin{array}{c}1.367 \\
(0.725-2.581)\end{array}$} & \multirow{2}{*}{$0.936(0.333)$} \\
\hline & Gln & 29 & (29) & 23 & (23) & & \\
\hline \multirow{2}{*}{ XPC } & Lys & 57 & (57) & 63 & $(63)$ & \multirow{2}{*}{$\begin{array}{c}1.284 \\
(0.729-2.265)\end{array}$} & \multirow{2}{*}{$0.750(0.386)$} \\
\hline & Gln & 43 & (43) & 37 & (37) & & \\
\hline
\end{tabular}

Table 4. Comparison of the combined effect of XPC and XRCC between PC patients and healthy control.

\begin{tabular}{|c|c|c|c|c|c|}
\hline \multicolumn{2}{|c|}{ Genotype } & \multirow{2}{*}{ Case $(n=50)$ n (\%) } & \multirow{2}{*}{ Control $(n=50)$ n $(\%)$} & \multirow{2}{*}{ OR (95\%) } & \multirow{2}{*}{$\begin{array}{c}\text { Test of association } \\
\mathbf{X}^{2} \text { (p-value) }\end{array}$} \\
\hline XPC & XRCC1 & & & & \\
\hline Lys/Lys + Lys/Gln & Arg/Arg + Arg/Gln & $33(66.0)$ & $42(84.0)$ & $0.370(0.142-0.962)$ & $4.320(0.038)$ \\
\hline Lys/Lys + Lys/Gln & GIn/Gln & $8(16.0)$ & $3(6.0)$ & $2.984(0.743-11.988)$ & $2.554(0.110)$ \\
\hline GIn/Gln & Arg/Arg + Arg/Gln & $5(10.0)$ & $9(18.0)$ & $0.506(0.157-1.635)$ & $1.329(0.249)$ \\
\hline GIn/Gln & GIn/Gln & 00.0 & 00.0 & -- & -- \\
\hline
\end{tabular}

Table 5. Association of the XPC Lys939GIn polymorphism with clinical parameters in prostate cancer patients.

\begin{tabular}{|c|c|c|c|c|c|c|c|}
\hline \multicolumn{2}{|c|}{ Genotype } & \multicolumn{2}{|c|}{ Lys/Lys + Lys/Gln $(\mathbf{n}=\mathbf{4 1})$} & \multicolumn{2}{|c|}{ Lys/Lys $(\mathbf{n}=\mathbf{9})$} & \multirow{3}{*}{$\begin{array}{c}\text { OR (95\%) } \\
0.579 \\
(0.127-2.636)\end{array}$} & \multirow{3}{*}{$\begin{array}{c}\text { Test of association } \\
\text { FEP }=0.713\end{array}$} \\
\hline \multirow{2}{*}{ Age } & $<70$ & 22 & $(54)$ & 6 & $(67)$ & & \\
\hline & $\geq 70$ & 19 & $(46)$ & 3 & (33) & & \\
\hline \multirow{2}{*}{$\begin{array}{c}\text { PSA } \\
\text { (ng/ml) }\end{array}$} & $<50$ & 21 & (51) & 7 & (78) & \multirow{2}{*}{$\begin{array}{c}0.300 \\
(0.056-1.620)\end{array}$} & \multirow{2}{*}{$\mathrm{FEP}=0.266$} \\
\hline & $\geq 50$ & 20 & (49) & 2 & $(22)$ & & \\
\hline \multirow{2}{*}{ Gleason } & $<7$ & 19 & (46) & 5 & (56) & \multirow{2}{*}{$\begin{array}{c}0.691 \\
(0.162-2.948)\end{array}$} & \multirow{2}{*}{$\mathrm{FEP}=0.721$} \\
\hline & $\geq 7$ & 22 & $(54)$ & 4 & $(44)$ & & \\
\hline \multirow{2}{*}{ Stage } & II & 22 & (54) & 4 & (44) & \multirow{2}{*}{$\begin{array}{c}1.447 \\
(0.339-6.177)\end{array}$} & \multirow{2}{*}{$\mathrm{FEP}=0.721$} \\
\hline & III/IV & 19 & (46) & 5 & $(56)$ & & \\
\hline
\end{tabular}




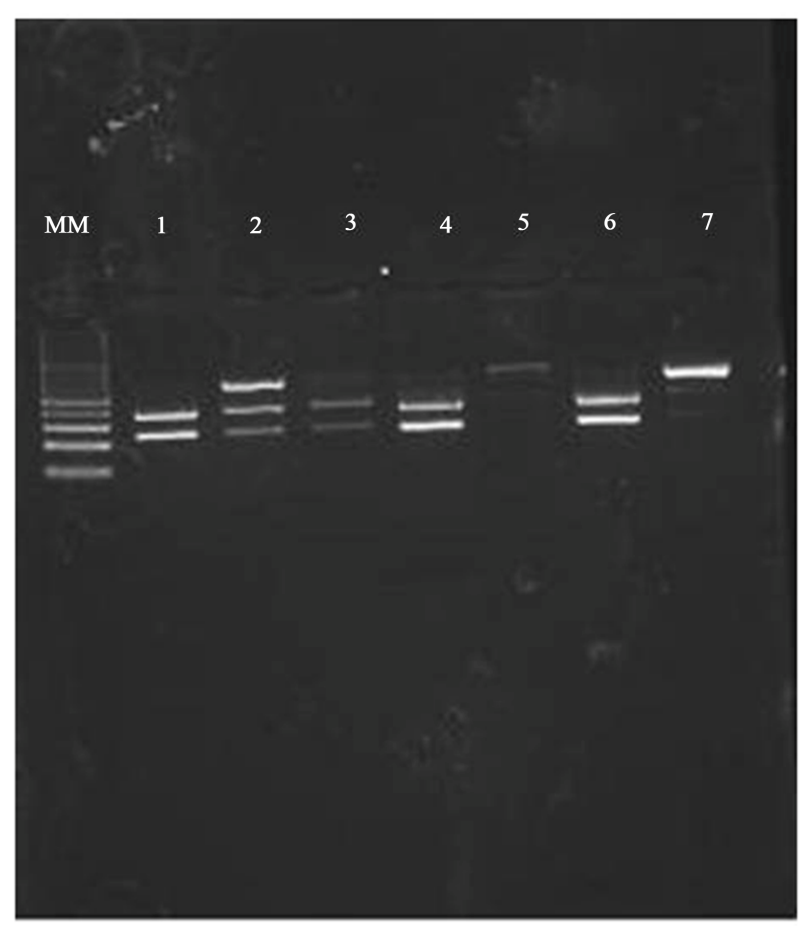

Figure 1. Agarose gel electrophoresis of the digested product of PvuII restriction endonuclease of XPC in 7 cases and controls. Lane MMshows a 50 bp molecular weight marker. Lanes 1, 3, 4 and 6 (131 bp, 150 bp) variant CC genotype. Lane 2 shows (281 bp, 150 bp and 130 bp)heterozygous mutated AC genotype, lanes 5 and 7 show (281 bp) wild type AA genotype.

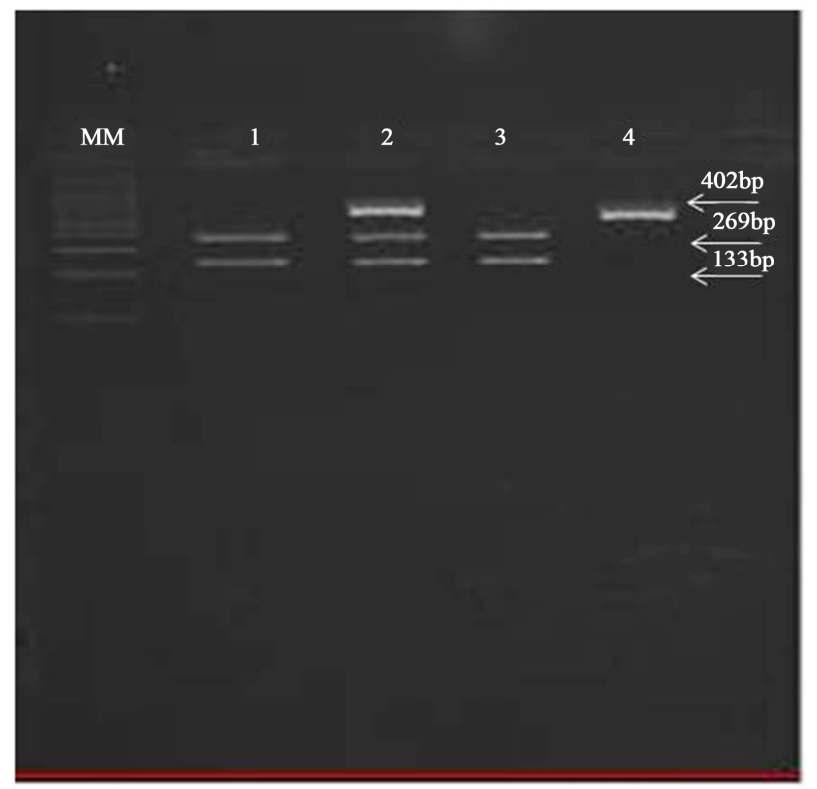

Figure 2. Agarose gel electrophoresis of the digested product of MspI restriction endonuclease of the XRCC1 in 4 subjects. Lane MM shows a 50 bpmolecular weight marker, Lanes 1 and 3 show wild type GG (269 bp, 133 bp), lane 2 shows heterozygous GA (402 bp, 269 bp and 133 bp), lane 4 shows variant AA (402 bp). to be lower in older age ( $\geq 70)$ group than in younger age group $(<70)(\mathrm{OR}=0.579,95 \% \mathrm{CI}=0.127-2.636)$ as well as in patients with higher PSA $(\geq 50)$ than in patients with lower PSA $(<50)(\mathrm{OR}=0.300,95 \% \mathrm{CI}=0.056$ $1.620)$. Yet, these associations were not statistically significant.

5. Relation of the XRCC1 polymorphism with clinical parameters in PC patients:

The associations between XRCC1 polymorphisms with clinico-pathological parameters were shown in Table 6. None of these associations were statistically significant. However, the frequency of Gln/Glnwas considerably higher in patients with high Gleason sum $(\geq 7)$ than in patients with low Gleason sum $(<7)$.

\section{Discussion}

Prostate Cancer is the most frequently diagnosed malignancy and a common leading cause of cancer death among males worldwide $[1,9]$.

Human DNA repair mechanisms protect the genome from DNA damage caused by endogenous and environmental agents. Genetic polymorphisms of DNA repair genes have been reported to lead to amino acid substitution in various cancers [4].

The XPC gene, located on chromosome 3p25, contains 16 exons and 15 introns and encodes a 940 amino acid protein [10]. Several polymorphic variants in the XPC gene have been identified and XPC Lys939Gln is one of the three most common SNPs.

It is located in the coding sequence of the XPC gene. The nucleotide change from $\mathrm{A}$ to $\mathrm{C}$ leads to an amino acid change from lysine to glutamine in the coding sequence of the XPC gene and has been reported to lead to reduced repair capacity. This genetic variation has also been reported to result in reduced specificity of this gene in recognition and repair of the DNA damage as well as in protein expression, thus allowing more somatic DNA mutations or alterations to occur $[11,12]$.

$X P C$ polymorphism was reported to be associated with the risk of many cancers, such as head and neck [13], lung [14], breast [15] and bladder [16].

XRCC1 is located on chromosome 19q13.2. The protein encoded by this gene is involved in the efficient repair of DNA single-strand breaks formed by exposure to ionizing radiation and alkylating agents. This protein interacts with DNA ligase III, polymerase beta and poly (ADP-ribose) polymerase to participate in the base excision repair pathway [17].

To our knowledge this is the first study to evaluate the risk of the XPC Lys939Gln and XRCC Arg399Gln polymorphisms with prostate cancer in a sample of Egyptian population.

Our results showed that no statistical difference in the genotype of XPC Lys939Gln between cases and controls. 
Table 6. Association of the XRCC1 Arg399GIn polymorphism with clinical parameters in prostate cancer patients.

\begin{tabular}{|c|c|c|c|c|c|c|c|}
\hline \multicolumn{2}{|c|}{ Genotype } & \multicolumn{2}{|c|}{$\operatorname{Arg} / \operatorname{Arg}+\operatorname{Arg} / \operatorname{Gln}(\mathbf{n}=\mathbf{4 2})$} & \multicolumn{2}{|c|}{$\mathrm{G} \ln / \mathrm{G} \ln (\mathbf{n}=\mathbf{8})$} & \multirow{3}{*}{$\begin{array}{c}\text { OR }(\mathbf{9 5 \%}) \\
1.333 \\
(0.293-6.064)\end{array}$} & \multirow{3}{*}{$\begin{array}{c}\text { Test of association } \\
\text { FEP }=0.718\end{array}$} \\
\hline \multirow{2}{*}{ Age } & $<70$ & 24 & $(57)$ & 4 & $(50)$ & & \\
\hline & $\geq 70$ & 18 & (43) & 4 & $(50)$ & & \\
\hline \multirow{2}{*}{ PSA (ng/ml) } & $<50$ & 24 & $(57)$ & 4 & $(50)$ & \multirow{2}{*}{$\begin{array}{c}1.333 \\
(0.293-6.064)\end{array}$} & \multirow{2}{*}{$\mathrm{FEP}=0.718$} \\
\hline & $\geq 50$ & 18 & (43) & 4 & $(50)$ & & \\
\hline \multirow{2}{*}{ Gleason } & $<7$ & 23 & $(55)$ & 1 & (12) & \multirow{2}{*}{$\begin{array}{c}8.474 \\
(0.956-75.082)\end{array}$} & \multirow{2}{*}{$\mathrm{FEP}=0.050$} \\
\hline & $\geq 7$ & 19 & $(45)$ & 7 & $(88)$ & & \\
\hline \multirow{2}{*}{ Stage } & II & 22 & $(52)$ & 4 & $(50)$ & \multirow{2}{*}{$\begin{array}{c}1.100 \\
(0.242-4.991)\end{array}$} & \multirow{2}{*}{$\mathrm{FEP}=1.000$} \\
\hline & $\mathrm{III} / \mathrm{IV}$ & 20 & (48) & 4 & $(50)$ & & \\
\hline
\end{tabular}

This is in contrast to the report that demonstrated that prostate cancer patients with at least one variant allele at XPC Lys939Gln had a slightly reduced risk of prostate cancer and a slightly reduced risk when both variants were present.

In the present study, we did not find a significant association between the genotype of the XRCC1 Arg399Gln and prostatic cancer cases or controls. Our findings are in agreement with the previously reported non-significant lower risk associated with this genotype in three different studies in the U.S. population [18-20]. However, two other studies found higher prostatic cancer risk for the carriers of this allele $[21,22]$.

A case-control study in China of 5 DNA repair markers found a positive association between PC risk and the XRCC1 399Gln/Gln genotype [18]. A significantly increased risk of $\mathrm{PC}$ was observed in white men with the XRCC1 399Gln allele (OR 1.6; 95\% CI 1.1 - 2.4). This study has found that white men with the following combined genotypes XRCC1 (399Arg/Gln_Gln/Gln)/APE1 $(51 \mathrm{Gln} / \mathrm{Gln})$ (OR: $4.0 ; 95 \% \mathrm{CI}: 1.3-12.5)$ and XRCC1 (399Arg/Gln_Gln/Gln)/APE1(148Asp/Asp) (OR: 2.9; 95\% CI: 1.4 - 6.1) genotypes have higher risk for PC [9]. However, another study reported reduced PC risk for men who carry 1 or 2 copies of the variant alleles at the XRCC 1 codons 194 and 399 compared with those who were homozygous for the common allele (OR: $0.8 ; 95 \%$ CI: 0.4 - 1.8 and OR_ $0.8 ; 95 \%$ CI, $0.5-1.3)$, respectively [19].

We also examined the combined effect of XPC Lys939Gln and XRCC1 Arg399Gln on prostate cancer risk, and the resultant ORs for XPC Lys939Gln (Lys/Lys + Lys/Gln) + XRCC1 Arg399Gln (Arg/Arg + Arg/Gln) were 0.370 . We found a decreased prostatic cancer risk when the previous genotypes were combined. In a study conducted by Hirata et al. [23], the results showed that an additional effect was not observed in the combined analysis compared to XPC Lys939Gln (Lys/Lys + Lys/ Gln). This was considered to be due to the increased fre- quencies of the XPC Lys allele.

\section{Conclusion}

In conclusion, our results suggested that there is no association between XPC Lys939Gln, XRCC1 Arg399Gln and PC risk. Although the combined effect of XPC Lys/Lys + Lys/Gln and XRCC1 Arg/Arg + Arg/Gln decreased PC risk, it didn't reach a statistically significant level. To our knowledge, this is the first report on the studies of XPC Lys939Gln and XRCC1 Arg399Gln polymorphisms in a sample of Egyptian prostatic cancer patients. Further studies with a larger sample size and other DNA repair polymorphisms that may play a role in the pathogenesis of PC and the inclusion of other environmental factors as smoking are necessary to confirm these findings.

\section{REFERENCES}

[1] A. Jemal, R. Siegel, E. Ward, Y. Hao, J. Xu, T. Murray and M. J. Thun, "Cancer Statistics, 2008," CA: A Cancer Journal for Clinicians, Vol. 58, No. 2, 2008, pp. 71-96. http://dx.doi.org/10.3322/CA.2007.0010

[2] K. C. Chu, R. E. Tarone and H. P. Freeman, "Trends in Prostate Cancer Mortality among Black Men and White Men in the United States," Cancer, Vol. 97, No. 6, 2003, pp. 1507-1516. http://dx.doi.org/10.1002/cncr.11212

[3] A. W. Partin, M. W. Kattan, E. N. Subong, P. C. Walsh, K. J. Wojno, J. E. Oesterling, et al., "Combination of Prostate-Specific Antigen, Clinical Stage, and Gleason Score to Predict Pathological Stage of Localized Prostate Cancer. A Multi-Institutional Update," JAMA, Vol. 277, No. 18, 1997, p. 1445. http://dx.doi.org/10.1001/jama.1997.03540420041027

[4] J. Xu, S. L. Zheng, A. Turner, et al., "Associations between hOGG1 Sequence Variants and Prostate Cancer Susceptibity," Cancer Res, Vol. 62, No. 8, 2002, pp. 2253-2257.

[5] El Goode, C. M. Ulrich and J. D. Potter, "Polymorphisms in DNA Repair Genes and Associations with Cancer 
Risk," Cancer Epidemiology, Biomarkers \& Prevention, Vol. 11, No. 12, 2002, pp. 1513-1530.

[6] M. C. Bosland, "Sex Steroids and Prostate Carcinogenesis: Integrated, Multifactorial Working Hypothesis," Annals of the New York Academy of Sciences, Vol. 1089, No. 1, 2006, pp. 168-176.

[7] A. Van Hoffen, A. S. Balajee, A. A. van Zeeland and L. H. Mullenders, "Nucleotide Excision Repair and Its Interplay with Transcription," Toxicology, Vol. 193, No. 1-2, 2003, pp. 79-90.

http://dx.doi.org/10.1016/j.tox.2003.06.001

[8] Y. Kubotta, R. A. Nash, A. Klungland, et al., "Reconstitution of DNA Base Excision-Repair with Purified Human Proteins: Interaction between DNA Polymerase Beta and the XRCC1 Protein," The EMBO Journal, Vol. 15, No. 23, 1996, pp. 6662-6670.

[9] D. M. Parkin, F. Bray, P. Ferlay and P. Pisani, "Global Cancer Statistics," CA: A Cancer Journal for Clinicians, Vol. 55, No. 2, 2005, pp. 74-108. http://dx.doi.org/10.3322/canjclin.55.2.74

[10] L. Li, C. Peterson and R. Legerski, "Sequence of the Mouse XPC cDNA and Genomic Structure of the Human XPC Gene," Nucleic Acids Research, Vol. 24, No. 6, 1996, pp. 1026-1028. http://dx.doi.org/10.1093/nar/24.6.1026

[11] Y. Zhu, H. Yang, Q. Chen, J. Lin, H. B. Grossman, C. P. Dinney, $\mathrm{X}$. Wu and J. Gu, "Modulation of DNA Damage/DNA Repair Capacity by XPC Polymorphisms," DNA Repair (Amst), Vol. 7, No. 2, 2008, pp. 141-148. http://dx.doi.org/10.1016/j.dnarep.2007.08.006

[12] S. I. Berndt, E. A. Platz, M. D. Fallin, L. W. Thuita, S. C. Hoffman and K. J. Helzlsouer, "Genetic Variation in the Nucleotide Excision Repair Pathway and Colorectal Cancer Risk," Cancer Epidemiology, Biomarkers \& Prevention, Vol. 15, No. 11, 2006, pp. 2263-2269. http://dx.doi.org/10.1158/1055-9965.EPI-06-0449

[13] H. Shen, E. M. Sturgis, S. G. Khan, Y. Qiao, T. Shahlavi, S. A. Eicher, Y. Xu, X. Wang, S. S. Strom, M. R. Spitz, K. H. Kraemer and Q. Wei, "An Intronic Poly (AT) Polymorphism of the DNA Repair Gene XPC and Risk of Squamous Cell Carcinoma of the Head and Neck: A Case-Control Study," Cancer Research, Vol. 61, 2001, pp. 3321-3325.

[14] S. Sanyal, F. Festa, S. Sakano, Z. Zhang, G. Steineck, U. Norming, H. Wijkström, P. Larsson, R. Kumar and K. Hemminki, "Polymorphisms in DNA Repair and Metabolic Genes in Bladder Cancer," Carcinogenesis, Vol. 25, No. 5, 2004, pp. 729-734. http://dx.doi.org/10.1093/carcin/bgh058

[15] H. Sugisawa, R. Nakamura, I. Nakano and A. Sugisawa, "Four-Year Follow-Up Study of Self-Rated Health and
Life Satisfaction among Caregivers," Nihon Koshu Eisei Zasshi, Vol. 39, 1992, pp. 22-32.

[16] L. Fontana, R. Bosviel, L. Delort, L. Guy, N. Chalabi, F. Kwiatkowski, S. Satih, N. Rabiau, J. P. Boiteux, A. Chamoux, Y. J. Bignon and D. J. Bernard-Gallon, "DNA Repair Gene ERCC2, XPC, XRCC1, XRCC3 Polymorphisms and Associations with Bladder Cancer Risk in a French Cohort," Anticancer Research, Vol. 28, No. 1, 2008, pp. 1853-1856.

[17] A. E. Vidal, S. Boiteux, I. D. Hickson, et al., "XRCC1 Coordinates the Initial and Late Stages of DNA Abasic Site Repair through Protein-Protein Interactions," The EMBO Journal, Vol. 20, No. 22, 2001, pp. 6530-6539. http://dx.doi.org/10.1093/emboj/20.22.6530

[18] J. D. Ritchey, W. Y. Huang, A. P. Chokkalingam, et al., "Genetic Variants of DNA Repair Genes and Prostate Cancer: A Population-Based Study," Cancer Epidemiology, Biomarkers \& Prevention, Vol. 14, No. 7, 2005, pp. 1703-1709. http://dx.doi.org/10.1158/1055-9965.EPI-04-0809

[19] G. H. van Gils, R. M. Bostick, M. C. Stern, et al., "Differences in Base Excision Repair Capacity May Modulate the Effect of Dietary Antioxidant Intake on Prostate Cancer Risk: An Example of Polymorphisms in the XRCC1 Gene," Cancer Epidemiology, Biomarkers \& Prevention, Vol. 11, No. 11, 2002, pp. 1279-1284.

[20] B. A. Rybicki, D. V. Conti, A. Moreira, et al., "DNA Repair Gene XRCC1 and XPD Polymorphism and Risk of Prostate Cancer," Cancer Epidemiology, Biomarkers \& Prevention, Vol. 13, No. 1, 2004, pp. 23-29. http://dx.doi.org/10.1158/1055-9965.EPI-03-0053

[21] L. Chen, C. B. Ambrosone, J. Lee, et al., "Association between Polymorphisms in the DNA Repair Genes XRCC1 and APEX1, and the Risk of Prostate Cancer in White and Black Americans," Journal of Urology, Vol. 175 , No. 1, 2006, pp. 108-112. http://dx.doi.org/10.1016/S0022-5347(05)00042-X

[22] Z. Xu, L. X. Hua, L. X. Qian, et al., "Relationship between XRCC1 Polymorphisms and Susceptibility to Prostate Cancer in Men from Han, Southern China," Asian Journal of Andrology, Vol. 9, No. 3, 2007, pp. 331-338. http://dx.doi.org/10.1111/j.1745-7262.2007.00263.x

[23] H. Hirata, Y. Hinoda, Y. Tanaka, N. Okayama, Y. Suehiro, K. Kawamoto, N. Kikuno, S. Majid, K. Vejdani and R. Dahiya, "Polymorphisma of DNA Repair Genes Are Risk Factors for Prostate Cancer," European Journal of Cancer, Vol. 43, No. 2, 2007, pp. 231-237. http://dx.doi.org/10.1016/j.ejca.2006.11.005 